\title{
НАСЛЕДОВАНИЕ ВЫМОРОЧНОГО ИМУЩЕСТВА В РФ.
}

После смерти лица может случиться так, что никто из наследников по завещанию или по закону не унаследует наследственное имущество. Такое имущество принято называть «выморочным» (bona vacantia, die Erbschaft erbenlos, die erblose Gueter, die erblose Verlassenschaften, les biens vacances, i beni vacanti).

Долгое время природа выморочного права вызывала споры среди ученых. к началу XX в. в немецкой пандектной доктрине сложились основные теории выморочного права, заимствованные русской цивилистикой. Суть их состоит в следующем:

1) право на выморочное наследство не может быть признано наследственным правом потому, что выморочным называется наследственное имущество при отсутствии наследников по закону и по завещанию либо если никто из наследников не примет наследство. С этой точки зрения выморочное право следует признать:

- правом обыкновенной оккупации;

- преимущественно предписанным правом оккупации, т. е. привилегированное оккупационное право для казны по завладению выморочным имуществом;

- суверенным правом, т. е. правом государства, основанном на праве владельца своей территории и находящихся на ней вещей;

- аналогичным цессии требования, поскольку и цессионарий и лицо, принявшее выморочное имущество, действуют в своих, а не в чужих интересах;

- аналогичным праву наследования, поскольку наследником может быть только физическое лицо, 
2) право на выморочное имущество следует отнести к наследственному праву. ${ }^{1}$

Некоторые ученые сочли, что право на выморочное имущество является универсальным преемством особого рода (successio universalis sui generis) и относится к институтам публичного, а не частного права. ${ }^{2}$

В настоящее время российский законодатель отнес право на выморочное имущество к наследственному праву, т. е. определил его как частно-правовой институт, поместив соответствующие нормы в главу 63 «Наследование по закону» раздела $\mathrm{V}$ «Наследственное право» части третьей Гражданского кодекса РФ. В соответствии с законом правовая природа выморочного имущества определена как переход имущества умершего физического лица в порядке наследования по закону к трем видам публично-правовых образований: муниципальным образованиям, субъектам российской Федерации - городам федерального значения Москве и Санкт-Петербургу, Российской Федерации, (п. 2 ст. 1151 ГК РФ). Сам порядок наследования и учета выморочного имущества, переходящего в порядке наследования по закону к публично-правовому образованию, должен определить специально принятый для этого законом (п. 3 ст. 11151 ГК РФ). Указанный закон в настоящее время пока ещё не принят, поэтому порядок наследования и учета выморочного имущества определяется ранее принятыми подзаконными нормативными актами, которые следует применять вплоть до принятия специального закона. ${ }^{3}$

Тем не менее, формулировки ст. 1151 ГК РФ могут вызвать определенные вопросы относительно правовой природы приобретения публично-правовым образованием выморочного имущества. Почему законодатель использует термин «переходит», а не «наследует» в отношении выморочного имущества? Существует ли разница в этих понятиях?

Слова законодателя о переходе прав и обязанностей относятся к различным ситуациям, которые складываются в связи возникновением и дальнейшим развитием наследственного правоотношения. В частности, в отношении:

- прав и обязанностей, «...переход которых в порядке наследования не допускается настоящим кодексом или другими законами» (абз. 2 ст. 1112 ГК РФ). морочные имущества. Киев. 1903. С. 41- 48

2 Рязановский В.А. О посмертном преемстве супругов по русскому праву. Историко-догматический очерк. Н.-Новгород. 1914. С. 139, 144.

3 Постановление Совмина СССР от 29.06.1984 N 683 (ред. от 25.07.1991) «Инструкция о порядке учета, оценки и реализации конфискованного, бесхозяйного имущества, имущества, перешедшего по праву наследования к государству, и кладов» (утв. Минфином СССР 19.12.1984 N 185) (ред. от 13.08.1991, с изм. от 15.01.2007); «Об утверждении Положения о порядке учета, оценки и реализации конфискованного, бесхозяйного имущества, имущества, перешедшего по праву наследования к государству, и кладов» 
- действий душеприказчика, основной обязанностью которого является - «обеспечить переход к наследникам причитающегося им наследственного имущества в соответствии с выраженной в завещании волей наследодателя и законом» (пп. 1 п. 2 ст. 1135 ГК РФ)

- наследника, обремененного легатом habitatio, «...к которому переходит жилой дом, квартира или иное жилое помещение» (абз. 2 п. 2 ст. 1137 ГК РФ),

- права на получения завещательного отказа, которое «...не переходит к другим лицам» (п. 4 ст. 1137 ГК РФ),

- перехода к другим наследникам обязанности исполнить завещательный отказ или завещательное возложение (ст. 1140 ГК РФ),

- к праву представления - «доля наследника по закону, умершего до открытия наследства или одновременно с наследодателем, переходит по праву представления к его соответствующим потомкам...» (п. 1 ст. 1146 ГК РФ),

- доли умершего супруга в отношении общего имущества супругов, которая входит в наследственную массу и переходит к его наследникам (ст. 1150 ГК РФ),

- права на обязательную долю, которое не переходит к наследникам necessarius'a (п. 3 ст. 1156 ГК РФ),

- к праву приращения наследственных долей и при наследовании по закону и при наследовании по завещанию - «часть наследства... переходит к наследникам по закону...» и «часть наследства... переходит к остальным наследникам по завещанию...» (п. 1 ст. 1161 ГК РФ),

- возникновения общей собственности наследников. Здесь следует обратить внимание на слова законодателя: «При наследовании по закону, если наследственное имущество переходит к двум или нескольким наследникам, и при наследовании по завещанию, если оно завещано двум или нескольким наследникам...» (абз. 1 ст. 1164 ГК РФ). В данном случае законодатель равнозначно использует понятие «наследование» и понятие «переход наследственного имущества к наследнику или наследникам»,

- наследования отдельных видов имущества - переход доли в уставном капитале хозяйственного общества (абз. 2 п. 1 ст. 1176 ГК РФ), пая потребительского кооператива (п. 2 ст. 1177 ГК РФ), земельного участка или права пожизненного наследуемого владения земельным участком (абз. 2 ст. 1181, п. 2 ст. 1182 ГК РФ). 
Как мы видим, законодатель использует понятие «переход», «переходит» при характеристике наследственных правоотношений. Переход имущества умершего ауктора синонимичен понятию «наследование», поскольку само содержание наследования и составляет переход прав и обязанностей умершего правопредшественника к правопреемнику («Объекты гражданских прав могут свободно ... переходить от одного лица к другому в порядке универсального правопреемства (наследование, реорганизация юридического лица)» п. 1 ст. 129 ГК РФ, «При наследовании имущество умершего (наследство, наследственное имущество) переходит к другим лицам в порядке универсального правопреемства...» п. 1 ст. 1110 ГК РФ). Свойство переходности является общим правилом в отношении субъективных прав и субъективных обязанностей. Исключения из этого правила прямо указаны как в общих положениях закона (например, ст.ст. 129, 383, 418 ГК РФ), так и в наследственном законодательстве (например, ст.ст. 1112, 1176 ГК РФ).

В этом отношении использование законодателем понятия «переход» относительно выморочного имущества совершенно корректно отражает содержание наследования. Ни в одном из приведенных случаев использования понятия «переход» и «переходит» невозможно выявить какого-либо иного смысла, чем описание содержания наследования. Следовательно, нет никаких причин, истолковывать иначе использование этого термина законодателем в отношении выморочного имущества. Формулировка законодателя не оставляет сомнения в том, что происходит именно наследование выморочного имущества или наследственное правопреемство, а не оккупация бесхозяйного имущества или нечто иное.

В настоящее время некоторые авторы выступают с критикой конструкции наследования выморочного имущества. Так, В.А. Белов придерживается мнения, что в ст. 1151 ГК РФ содержится внутреннее противоречие - не может быть имущество выморочным и одновременно перейти в порядке наследования. Если имущество выморочное, то оно переходит к государству путем оккупации, т. е. актом одностороннего захвата со стороны государства. Тем не менее, В.А. Белов признает подобие выморочного имущества наследственной массе, т. к. оно включает в себя и активы, и пассивы умершего лица, но в целом считает, что «правила о выморочном имуществе и его переходе к государству не имеют ничего общего с нормами наследственного права». ${ }^{4} \mathrm{~B}$ данном случае позиция автора противоречит прямому указанию закона и общей тенденции, окончательно возобладавшей ещё в ГК РСФСР 1964 г., - считать государство наследником имущества, которое не перешло к другим наследниками 
по закону или завещанию. ${ }^{5}$ Позиция В.А. Белова представляется нам весьма слабой и с теоретической точки зрения, поскольку оккупация является первоначальным способом приобретения права собственности на имущество, а переход прав и обязанностей к публично-правовому образованию от умершего праводателя по ныне действующему праву является производным способом. ${ }^{6}$

Сходную позицию занимает М.В. Телюкина, говоря, что при наследовании выморочного имущества «речь по сути идет не о наследовании, а о получении выморочного имущества ... для предотвращения путаницы в дефинициях и их содержании применительно к выморочному имуществу следует употреблять термин не «наследование», а «получение». ${ }^{7}$ В связи с этим следует отметить, что тот или иной термин подразумевает описание вполне определенного правового явления с присущим ему юридическим содержанием. Если в законе совершенно ясно речь идет о наследовании, то более общий термин «получение» не может правильно отразить правовую сущность перехода имущества умершего к публично-правовому образованию. Позиция законодателя в этом вопросе выражена совершенно однозначно, и с ней следует считаться.

Более важным и практически значимым, нам представляется, вопрос о правовой природе наследования выморочного имущества, особенностях такого наследования.

Ответ на этот вопрос позволит определить:

а) какие правовые нормы и в каком объеме следует применять к отношениям, возникающим при переходе выморочного имущества,

б) правовые последствия такого перехода:

- будут ли иметь силу распоряжения умершего, содержащиеся в завещании? В частности: переходит ли обязанность исполнить завещательный отказ или завещательное возложение при наследовании выморочного имущества к Российской Федерации, а в случаях наследования жилых помещений к муниципальным образованиям, Москве или Санкт-Петербургу?

- в каком порядке публично-правовое образование будет отвечать по долгам наследодателя?

5 Комментарий к части третьей Гражданского кодекса Российской Федерации / Под ред. А.Л. Маковского, Е.А. Суханова. М.: 2002. С. 197-198 (автор комментария - А.А. Рубанов).

6 Российское гражданское право: Учебник: В 2 т. Т. І: Общая часть. Вещное право. Наследственное право. Исключительные права. Личные неимущественные права / Отв. ред. Е.А. Суханов. М.: Статут. 2010. С. 662 (автор главы - Е.В. Кулагина).

7 Телюкина М.В. Наследственное право: Комментарий Гражданского кодекса Российской Федерации: Учебно-практическое пособие. М.: Дело. С. 110. 
Проанализируем правила о наследовании выморочного имущества с догматической, исторической и сравнительно-правовой точек зрения.

Прежде всего, следует обратить внимание на формулировку законодателя - к публично-правовому образованию выморочное имущество переходит «в порядке наследования по закону в собственность» (п. 2 ст. 1151 ГК РФ).

Почему законодатель говорит о переходе наследственного имущества к данному субъекту «в порядке наследования по закону», а не просто «в порядке наследования»? как это следует понимать: как ещё одно основание наследования или синоним наследования по закону? Следует ли в таком случае считать, что публично-правовое образование не становится наследником по закону, а становится наследником в порядке наследования по закону? Применимы ли в отношении публично-правового образования основные понятия наследственного права, используемые законодателем, такие как: «наследник», «наследник по закону», «наследник, призванный к наследованию», «наследник по закону, призванный к наследованию» и т. п.? Норма не вполне ясна. Нам представляется, что для ответа на поставленные вопросы одного лишь грамматического толкования недостаточно. Следует прибегнуть к систематическому и логическому толкованиям, которые позволят понять смысл и внутреннюю связь правовых норм, регулирующих выморочное право, как единое целое. ${ }^{8}$

Употребление слов «в порядке» повсеместно встречается в гражданском законодательстве, например в п. 4 ст. 469, п. 2 ст. 502, п. 2 ст. 544 ГК РФ и т. д. В связи с наследованием законодатель говорит:

- об имуществе, полученном в дар или «в порядке наследования» (абз. 2 п. 2 ст. 256 ГК РФ),

- о правах и обязанностях, «переход которых в порядке наследования не допускается» (абз. 2 ст. 1112 ГК РФ),

- о наследовании «в порядке наследственной трансмиссии» (п. 1 ст. 1156 ГК РФ),

Когда устанавливает общее правило для всех случаев наследования. «При наследовании имущество умершего (наследство, наследственное имущество) переходит в порядке универсального правопреемства...» (п. 1 ст. 1110 ГК РФ). Согласно этому правилу наследование всегда есть переход имущество умершего в определенном (завещанием или законом) порядке. 
Кроме того, ранее действовавший Закон РФ от 12.12.1991 г. №2020-1 «О налоге с имущества, преходящего в порядке наследования или дарения» в п. 1 ст. 3 «Ставки налога» упоминал налог с имущества, «переходящего физическим лицам в порядке наследования». Полезным будет провести сравнение с определением в п. 2 ст. 3 того же закона: «Налог с имущества, переходящего физическим лицам в порядке дарения...». Если предположить, что здесь имеется в виду ещё одно основание наследования, то в случае с дарением следует предположить, что здесь имеет место не дарение, а переход имущества в порядке дарения. В ныне действующем Налоговом кодексе РФ воспроизведены прежние формулировки «в порядке наследования»: в пп. 9 п. 10 ст. 214.1 Нк РФ - наследник-налогоплательщик получил ценные бумаги «в порядке наследования», в п. 18 ст. 217 Нк РФ о доходах в денежной и натуральной формах, полученных «в порядке наследования», в пп. 2 п. 2 ст. 251 Нк РФ - имущество и имущественные права, переходящие к некоммерческим организациям по завещанию в порядке наследования.

В связи с вышесказанным обращает на себя внимание содержание п. 2 ст. 1116 ГК РФ, где говориться, что Российская Федерация, субъекты Российской Федерации, муниципальные образования могут призываться «к наследованию по закону». Законодатель определяет, что наследование по закону публичноправовыми образованиями происходит «в соответствии со статьей 1151 настоящего кодекса» (п. 2 ст. 1116 ГК РФ). По мнению А.А. Рубанова, п. 2 ст. 1151 ГК РФ «...воспроизводит нормы, уже установленные в п. 2 ст. 1116 ГК». ${ }^{9}$ Обращает на себя внимание, что по общему правилу публично-правовое образование призывается к наследованию «по закону», а не «в порядке наследования по закону». С одной стороны, слова «в порядке наследования по закону» описывают содержание наследственного правоотношения при наследовании имущества как выморочного, с другой, указывают на отсутствие какого-то особого порядка наследования выморочного имущества публично-правовым образованием.

Анализ нормативного материала позволяет нам сделать вывод: когда законодатель указывает на то, что нечто совершается в определенном порядке, он отвечает на вопрос - как происходит сам процесс и какие правила при этом следует применять, например, правила о наследовании по закону или по завещанию, или правила о дарении и т. п.

Употребление слов «в порядке наследования» по завещанию или закону равнозначно термину «наследование» по завещанию или по закону. Никакой 
иной смысл путем грамматического, систематического и догматического толкования нам не удается здесь выявить.

Кроме того, закон прямо указывает, что существуют только два основания наследования - наследование по завещание и по закону (ст. 1111 ГК РФ), т. е. определяет, в каком порядке осуществляется наследование. При наличии завещания следует руководствоваться изложенной в нем волей завещателя, а при отсутствии завещания правилами, установленными на этот случай в законе. Следовательно, любое наследование, которое будет происходить не по воле завещателя, есть наследование по закону.

Следует также обратить внимание и на императивную норму закона о приобретении права собственности в случае смерти гражданина, согласно которой «...право собственности на принадлежавшее ему имущество переходит по наследству к другим лицам в соответствии с завещанием или законом» (абз. 2 п. 2 ст. 218 ГК РФ). Никаких иных вариантов законом не предусмотрено. Публично-правовое образование наследует выморочное имущество в соответствии с законом, что равнозначно выражению «наследование по закону».

Ведь не случайно законодатель поместил нормы о наследовании выморочного имущества в раздел «Наследование по закону», и чтобы избежать какихлибо разногласий подчеркнул, что выморочное имущество переходит к публично-правовому образованию в порядке наследования по закону. Но может быть, включение в главу 63 «Наследование по закону» правил о наследовании выморочного имущества имеет техническое значение, поскольку было бы неоправданным выделять в отдельную главу весьма краткие правила о наследовании выморочного имущества? Подобного рода аргумент может быть воспринят только в случае, если бы у нас имелись соответствующие разъяснения законодателей. Но даже в этом случае нам следует руководствоваться законом, а не мотивами авторов закона.

Большинство исследователей считает, что Российская Федерация и иные публично-правовые образования являются наследниками по закону, а не особым, отличным от него, видом наследника. ${ }^{10}$ Подобного мнения придерживались отечественные цивилисты и при анализе норм о выморочном имуществе

10 Комментарий к Гражданскому кодексу Российской Федерации: В 3 т. Т. 3. Комментарий к Гражданскому кодексу Российской Федерации, части третьей / под ред. Т.Е. Абовой, М.М. Богуславского, А.Г. Светланова; Институт государства и права РАН.М.: Юрайт-Издат. 2004. С. 147. (автор комментария А.А. Рубанов) Встречается и ещё более категоричное мнение: «С определенной долей условности Российскую Федерацию можно поставить в девятую очередь наследников по закону» - Зайцева Т.И., Крашенинников П.В. Наследственное право в нотариальной практике: комментарии (ГК РФ, ч. 3, разд. V), метод. Рекомендации, образцы док., норматив. Акты, судеб. Практика: практическое пособие / Федеральная нотариальная палата России. Центр нотариальных исследований. 5-е изд. М.: Волтерс Клувер. 2007. С. 211. 
ГК РСФСР 1922 г., ${ }^{11}$ и норм о наследовании государством ГК РСФСР 1964 г. и соответствующего гражданского законодательства союзных республик. ${ }^{12}$

Как следует истолковать указание закона в п. 1 ст. 1151 ГК РФ, что имущество считается выморочным «...если отсутствуют наследники, как по закону, так и по завещанию»? Откуда берет свое происхождение эта формулировка?

В русском дореволюционном праве в ст. 1162 Т. Х, ч. 1 Свода законов говорится о выморочности наследства, если «не останется вовсе наследников», и в ст. 1167, что «выморочное имущество обращается в казну». Судебная практика истолковала положения закона о выморочном имуществе, как «один из видов приобретения имуществ наследством по закону». ${ }^{13}$ Русские цивилисты того времени также считали, что в данном случае имеет место наследование по закону. ${ }^{14}$ На противоречие формулировки ст. 1162 и признания государства наследником по закону обратил внимание В.И. курдиновский. В своем обстоятельном исследовании он показал эволюцию данной терминологии, начиная со времен римского права, и в силу правовой традиции закрепленную в зарубежных законах XIX в. ${ }^{15}$ В русском праве, с его точки зрения, несомненно, имеется неточность легальной дефиниции о выморочных имуществах, что имеет свое историческое объяснение. De lege ferenda B.И. курдиновский предлагал сформулировать правило о выморочном имуществе, как «право наследования без завещания, в котором принадлежит указанным в законе юридическим лицам». ${ }^{16}$

Проект Гражданского уложения 1905 г. в ст. 1373. - «за отсутствием лиц, имеющих право наследования, наследство признается выморочным» - не связывал напрямую переход выморочного имущества в порядке наследования. ГК РСФСР 1922 г. в ст. 433 в целом воспроизводит правила Проекта Гражданского уложения: «В случае неявки наследников в течение шести месяцев по принятии мер охранения наследственного имущества, а равно в случае отказа наследников от наследства (за исключением случая, предусмотренного ст. 424), имущество признается выморочным, и поступает в распоряжение соответствующих органов государства».

11 Орлов Н. Правовая природа выморочного имущества / Вопросы советского гражданского права. М. 1955. С. 117; Серебровский В.И. Очерки советского наследственного права / Избранные труды по наследственному и страховому праву. М. 2003. С. 245-246; Черепахин Б.Б. Правопреемство по советскому гражданскому праву / Труды по гражданскому праву. М. 2001. С. 435-436.

12 Дроников В.К. Наследственное право Украинской ССР. Киев. 1974. с. 68; Иоффе О.С., Толстой Ю.К. Основы советского гражданского законодательства. Л., 1962. С. 214 (автор главы - Ю.К. Толстой); Никитюк П.С. Наследственное право и наследственный процесс.(Проблемы теории и практики). Кишинев. 1973. С. 107-109; Степаненко Г.М. Наследственное право РСФСР. Саратов. 1965. С. 23. Законы гражданские с разъяснениями Правительствующего Сената и комментариями русских юристов. Составил И.М. Тютрюмов. Книга третья. М. 2004. С. 262.

14 Обзор точек зрения см.: Курдиновский В.И. Выморочные имущества // ЖМЮ. 1902, кн. 5, с. 152-154, 161.

15 Курдиновский В.И. Выморочные имущества // ЖМЮ. 1902, кН. 5, с. 150-151.

16 Курдиновский В.И. Выморочные имущества // ЖМЮ. 1902, кн. 5, с. 154-161. 
Однако в ст. 552 ГК РСФСР 1964 г. законодатель, пытаясь снять противоречие между указанием в законе на выморочность имущества и одновременно на переход его к государству в порядке практически мало чем отличающимся от наследования. ${ }^{17}$ Практически здесь имеет место возврат к неудачной формулировке ст. 1162 Т. Х, ч. 1 Свода законов. ${ }^{18} \mathrm{~B}$ несколько измененном и значительно расширенном виде это правило было воспроизведено в ст. 1151 ГК РФ.

Формулировку п. 1 ст. 1151 ГК РФ следует толковать в связи с п. 2 ст.1116, п. 2 ст. 1151 ГК РФ, названием раздела главы. Публично-правовое образование следует считать наследником по закону sui generis. Указания на наследников в п. 1 ст. 1151 ГК РФ подлежат ограничительному толкованию, т. е. под наследниками по закону следует понимать наследников-физических лиц, наследующих в порядке очередности, предусмотренной ст. 1142-1145, 1148, 1156, 1158, 1161 ГК РФ.

В связи с этим Ю.К. Толстой весьма тонко выявил смысл юридико-технического приема, который применил законодатель при использовании понятий «выморочное имущество» и «наследник по закону». По его мнению, применение понятия «выморочное имущество» как раз и позволяет в составе имущества, переходящего по праву наследования к государству, выделить то, которое переходит к государству как к особому наследнику по закону потому, что других наследников ни по закону, ни по завещанию нет». ${ }^{19}$

Насколько наследование выморочного имущества отличается от наследования по закону?

Для ответа на этот вопрос следует рассмотреть особенности наследования выморочного имущества.

Имущество считается выморочным при наличии следующих условий:

- будут отсутствовать наследники как по закону, так и по завещанию,

- никто из наследников не будет иметь права наследовать,

- все наследники будут отстранены от наследования,

- никто из наследников не примет наследства,

- все наследники откажутся от наследства, и при этом никто из них не укажет, что отказывается в пользу другого наследника,

Обращает на себя внимание специальный субъектный состав участников наследственного правоотношения, определенный законом. В зависимости от

17 «Советское государство выступает в этом случае в качестве особого рода наследника по закону» - Антимонов Б.С., Граве К.А. Советское наследственное право. М. 1955. С. 236.

18 Ст. 552 ГК РСФСР: «если у наследодателя нет наследников ни по закону, ни по завещанию».

19 Гражданское право. Том 3. Учебник. Изд. третье, перераб. и доп. / Под ред. А.П. Сергеева, Ю.К. Толстого. M. 2000. C. 569 . 
вида наследственного имущества оно переходит либо муниципальным образованиям, либо к таким субъектам РФ как г. Москва, г. Санкт-Петербург, либо к Российской Федерации. к другим субъектам Российской Федерации, физическим или юридическим лицам выморочное имущество перейти не может. Законодатель определил, что к муниципальным образованиям, г. Москве и г. Санкт-Петербургу переходят только жилые помещения. Все остальное имущество наследует РФ. Такое положение закона, несомненно, нарушает один из основополагающих принципов наследования - принцип универсального правопреемства. До внесения изменения в закон в $2007 \Gamma^{20}{ }^{20}$ выморочное имущество как единое целое переходило к Российской Федерации. Нарушение принципа универсальности наследственного правопреемства вызвано политикой права. Муниципальным образованиям, г. Москве и Санкт-Петербургу предоставлены дополнительные возможности для приобретения жилых помещений. Ведь именно на них в первую очередь возложена обязанность по предоставлению малоимущим гражданам, нуждающимся в жилых помещениях, жильё по договору социального найма (п. 2 ст. 49 ЖК РФ).

Является ли отход от принщипа универсального правопреемства особенностью перехода выморочного имущества к публично-правовому образованию?

На этот вопрос следует ответить отрицательно. Принцип универсального правопреемства закреплен в ст. 1110 ГК РФ, как общее правило. Однако законодатель отходит от этого принципа, предоставляя наследнику как по закону, так и по завещанию, широкие возможности выбирать основание для принятия наследства (абз. 2 п. 2 ст. 1152 ГК РФ). Более того, закон допускает для наследника даже в рамках одного основания выбор, в каком качестве он будет принимать наследство. Например, после смерти наследодателя Иванова остались три сына Петр, Павел, Семён. Петру была завещана квартира наследодателя. Денежный вклад в банке, дача, предметы обычной домашней остановки остались не завещанными. Петр может унаследовать только завещанную ему квартиру и отказаться наследовать остальное имущество. В случае смерти Павла после открытия наследства, если у него не осталось наследников первой очереди, и он не составил завещания, то у Петра появляется выбор в рамках наследования по закону - принять причитающуюся ему часть незавещанного имущества отца, или принять по праву наследственной трансмиссии ту часть отцовского незавещанного имущества, которая причиталась умершему брату.

В связи с этим вполне допустима ситуация, когда наследник принял только завещанную ему часть имущества и отказался принимать остальное имущество или часть имущества, причитающуюся ему как наследнику по закону. 
В случае отсутствия других наследников незавещанная часть имущества становится выморочной, т. е. в российском праве допускается частичная выморочность наследства. В ст. 552 ГК РСФСР 1964 г. содержалось прямое указание на возможность частичной выморочности наследственного имущества.

Распространяются ли правила о призвании к наследству на публично-правовое образование? Следует ли его считать наследником, призванным к наследству?

В законе указывается перечень наследников по закону, которые призываются к наследству - «Наследники по закону призываются к наследованию в порядке очередности, предусмотренной статьями 1142 - 1145 и 1148 настоящего кодекса» (п. 1 ст. 1141 ГК РФ).

В отношении выморочного имущества такого указания не содержится. Возможно перед нами квалифицированное умолчание законодателя? На этот вопрос следует ответить отрицательно. Закон определил общую категорию «Лица, которые могут призываться к наследованию» (ст. 1116 ГК РФ). ${ }^{21}$ к ним относятся граждане и юридические лица, Российская Федерация, субъекты Российской Федерации, муниципальные образования, иностранные государства и международные организации. При этом физические лица, Российская Федерация, субъекты Российской Федерации, муниципальные образования могут призываться к наследованию как по закону, так и по завещанию.

Наследование выморочного имущества не связано с какой-либо очередностью. Публично-правовые образования всегда призываются к наследованию последними, поскольку их призвание к наследству возможно только в случае, если не унаследуют оставшееся после смерти наследодателя имущество наследники по завещанию или другие наследники по закону.

При призвании публично-правового образования к наследству у него не возникает секундарного права на принятие наследства, а сразу же возникает право на наследство.

Публично-правовое образование не может отказаться от наследства при наследовании выморочного имущества (абз. 2 п. 1 ст. 1157 ГК РФ). Все другие наследники, в том числе и публично-правовые образования, призванные к наследству по завещанию, обладают таким правом (абз. 1 п. 1 ст. 1157 ГК РФ). Публично-правовое образование выступает в качестве необходимого на-

21 «к наследованию по завещанию могут призываться Российская Федерация, субъекты Российской Федерации, муниципальные образования, иностранные государства и международные организации, а к наследованию по закону - Российская Федерация, субъекты Российской Федерации (следует толковать ограничительно на основании ст. 1151 ГК РФ - г. Москва и г. С.-Петербург - А.А. Н.), муниципальные образования в соответствии со статьей 1151 настоящего кодекса». Тире заменяет слова «могут призываться». 
следника или наследника по принуждению закона (der Staat nach dem Gesetz Zwagserbe ist, der Staat als Zwangserbe). ${ }^{22}$

Публично-правовое образование не может быть признано недостойным наследником, как, впрочем, и любое юридическое лицо. Закон прямо указывает, что это правило касается только наследников - физических лиц:

граждан, совершавших умышленные противоправные действия, направленные против наследодателя, кого-либо из его наследников или против осуществления последней воли наследодателя, выраженной в завещании, способствовали либо пытались способствовать призванию их самих или других лиц к наследованию либо способствовали или пытались способствовать увеличению причитающейся им или другим лицам доли наследства (абз. 1 п. 1. ст. 1117 ГК РФ),

граждан, злостно уклонявшихся от выполнения лежавших на них в силу закона обязанностей по содержанию наследодателя (п. 2 ст. 1117 ГК РФ),

родители после детей, в отношении которых родители были в судебном порядке лишены родительских прав и не восстановлены в этих правах ко дню открытия наследства (абз. 2 п. 1. ст. 1117 ГК РФ).

Сложные отношения между публичной властью и гражданами РФ, когда государство не исполняло или ненадлежащим образом исполняло свои обязанности по социальному обеспечению умершего гражданина, или вследствие государственной социально-экономической политики наследодатель оказался в тяжелом материальном положении, приводит некоторых современных российских авторов к выдвижению предложений включить в закон нормы о признании государства недостойным наследником. ${ }^{23}$

В связи с этим следует отметить, что данные предложения противоречат самой сути права выморочного имущества. По смыслу закона последним всегда остается государство как необходимый наследник, поэтому государство как законный наследник не может отпасть вследствие его недостойности. ${ }^{24}$

По причине того, что государство или иное публично-правовое образование является последним законным наследником, наследодатель не может лишить наследства публично-правовое образование. Следует истолковывать п. 1 ст. 1119 ГК РФ ограничительно. Завещатель вправе лишить наследника по закону наследства, кроме наследника выморочного имущества. Распоряжение

22 Brox H. Erbrecht. Koeln, etc. 1994. S. 55-56.

23 Котухова М.В. Гражданско-правовое регулирование отношений с выморочным имуществом в наследственном праве РФ. Автореф. М. 2007.

24 Brox H. Erbrecht. Koeln, etc. 1994. S. 56. 
наследодателя о лишении наследства публично-правового образования следует признать недействительным, как противоречащим закону.

Возможен ли отказа от наследства в пользу публично-правового образования?

В отличие от ранее действующего закона, который прямо указывал на возможность отказа от наследства в пользу государства (ст. 552 ГК РСФСР), ${ }^{25}$ в ныне действующем Гражданском кодексе такое правило отсутствует. Настоящие правила о наследовании допускают возможность совершить направленный отказ в пользу публичного образования только в том случае, когда публично-правовое образование назначено наследодателем наследником по завещанию. Если публично-правовое образование отказалось наследовать по завещанию или не приняло наследство на этом основании, то следует иметь в виду, что в п. 2 с. 1158 ГК РФ содержится прямой запрет: «Отказ от наследства в пользу лиц, не указанных в пункте 1 настоящей статьи, не допускается». В п. 1 ст. 1158 ГК РФ указаны лица, в пользу которых наследник вправе отказаться от наследства: наследники по завещанию, наследники по закону любой очереди, в том числе призванных по праву представления и в порядке наследственной трансмиссии, не лишенных наследства в соответствии с п. 1 ст. 1119 ГК РФ. Следует обратить внимание на указание законодателя на то, что направленный отказ возможен только в отношении наследников какой-либо очереди. Наследование выморочного имущество не относится к какой-либо очереди наследования, поэтому при наследовании части имущества как выморочного публичным образованием наследник по завещанию, наследующий другую часть наследственного имущества, не вправе отказаться в пользу этого образования от причитающегося ему наследства. Расширительного толкования в этом случае быть не может, т. к. п. 2 ст. 1158 прямо говорит о закрытом перечне таких лиц.

Возможно ли обременить публично-правовое образование легатом или модусом?

В римском праве установилось мнение, выраженное Гаем, что в случае перехода наследственного имущества к фиску, сохраняются легаты и распоряжения об отпуске рабов на свободу. ${ }^{26}$ Юлиан прямо говорит о необходимости совершить предоставления по фидеикомиссам и легатам, которыми был обременен наследник, при переходе выморочного имущества к фиску. ${ }^{27}$ Римляне, с некоторыми оговорками, допускали возможность обременить государ-

Бондарев Н.И., Эйдинова Э.Б., Яковлева А.Л. Нотариат. «Юридическая литература». М. 1968. С. 69.

D. 49. 14.14 - cum ex quibuslibet aliis causis fisco vindicates hereditatibus et libertates et legata maneant.

D. 30. 96.1 - quotiens lege lulia bona vacantia ad fiscum pertinent, et legata et fideicommissa praestantur, quae praestare cogeretur heres a quo relicta errant. 
ство с помощью завещания обязанностью предоставить содержание частных лицам. ${ }^{28}$

В русском дореволюционном наследственном праве не признавалась сама возможность обременить завещательным отказом наследника по закону. ${ }^{29}$ В соответствии с ГК РСФСР 1922 г. обременение легатом государства было невозможно, т. к. ст. 423 прямо отсылает к ст. 418, где указаны только наследники-физические лица. Соответственно государство не обязано исполнять завещательные отказы при переходе к нему выморочного имущества. В отношении modus'a Е.А. Флейшиц делает исключение: «...при назначении наследником государственного органа или общественной организации завещатель имеет право указать определенную цель, на которую должно быть употреблено имущество». ${ }^{30}$

Однако положение коренным образом изменилось с принятием в 1961 г. «Основ гражданского законодательства СССР и союзных республик» и нового ГК РСФСР в 1964 г. Теперь в соответствии с communis opinio doctorum наследодатель был вправе обременить легатом любого наследника по завещанию, в том числе и государство. ${ }^{31}$ Эта обязанность оставалась и при наследовании выморочного имущества. Так, В.А. Рясенцев считал, что «даже если наследство, обремененное отказом, получает государство, то и оно обязано выполнить его». ${ }^{32}$ Такого же мнения придерживается Э.Б. Эйдинова ${ }^{33}$ и Ю.К. Толстой: «если наследник, на которого завещатель возложил исполнение легата, отказался от наследства и наследственное имущество в порядке ст. 552 перешло к государству, легатарий вправе требовать исполнение легата от государства в лице соответствующих органов». ${ }^{34}$

В настоящее время одни ученые считают, что обязанность исполнить завещательный отказ переходит к Российской Федерации, субъектам Российской Федерации и муниципальным образованиям, при переходе к ним выморочного имущества. ${ }^{35}$

\footnotetext{
28 D. 34. 1. 20. 1 - benigna voluntatis interpretatione dici his quoque a re publica praestanda.

29 Вавин Н.Г. Завещательный отказ по русскому праву. М. 1915. С. 52.

30 Флейшиц Е.А. Завещание и легат в советском гражданском праве // Всесоюзный институт юридических наук. Ученые записки. Вып. VI.M. 1946. С.84, 94.

31 Иоффре О.С. Советское гражданское право. Курс лекций. Ч. ІІІ. (Правоотношения, связанные с продуктами творческой деятельности. Семейное право. Наследственное право). Изд. ЛГУ.Л. 1965. С. 320.

Рясенцев В.А. Наследование по закону и по завещанию в СССР.М. 1972. С. 28.

Эйдинова Э.Б. Наследование по закону и завещанию. М. 1984. С. 47-48.

Иоффе О.С., Толстой Ю.К. Новый Гражданский кодекс РСФСР.Л.: ЛГУ. 1962. С. 429. (автор главы Ю.К. Толстой)

35 Виноградов Р.И., Дмитриева Г.К., Репин В.С. комментарий к Гражданскому кодексу Российской Федерации, части третьей / Под общ. рец. проф. В.П. Мозолина. М. 2006. С. 97.Гражданское право: учебник в 3-х т. Т. 3 / Под ред. А.П. Сергеева. М.: Велби. 2009. С. 677 (Н.Н. Аверченко)
} 
Другие ученые и юристы-практики считают, что обязанность по исполнению легата к публичным образованиям не переходит. Они аргументируют свою точку зрения следующими доводами:

- публичное образование не может отказаться от выморочного имущества, поэтому нельзя обязать его в одностороннем порядке. Односторонней сделкой можно обязать лицо только в случае прямо указанном в законе. Такого указания в законе нет, а оно не может предполагаться. Следует указать на ошибочность этого мнения. Такое указание в законе есть - ст. 1140 ГК РФ говорит о переходе к другим наследникам обязанности исполнить завещательный отказ. Публично правовое образование является наследником и в его отношении закон не делает никакого исключения.

- публичное образование наследует имущество не по закону, а «в порядке наследования по закону». Включение в главу 63 «Наследование по закону» правил о наследовании выморочного имущества имеет техническое значение, поскольку было бы неоправданным выделять в отдельную главу весьма краткие правила о наследовании выморочного имущества. Публичное образование не становится наследником по закону. Оно становится наследником в порядке наследования по закону. Следовательно, публичное образование не обязано исполнять завещательный отказ. В силу прямого указания закона обязанными к исполнению легата лицами могут быть только наследники по завещанию или по закону (п. 1 ст. 1137 ГК РФ).

Кроме выше приведенных аргументов мы можем рассмотреть эти доводы с точки зрения Begriffsjurisprudenz.

Обязательство из завещательного отказа является обязательством sui generis. Это обязательство исполняется только в пределах стоимости перешедшего к обязанному лицу наследственного имущества. Публичное образование, приобретая выморочное имущество, получает имущественную выгоду, происходит увеличение его имущества. Завещательный отказ может только уменьшить размер этой выгоды, но никак не обязывает наследника к большему, чем он получает из наследственного имущества. Завещание - это именно та односторонняя сделка, которой одно лицо вправе обязать другое исполнить указанные в нём распоряжения.

Допустим, что публичное образование при наследовании выморочного имущества не становится наследником по закону, а становится наследником «в порядке наследования по закону». Что же это за «порядок наследования по закону»? Порядок наследования по закону, прежде всего, определен в главе 63 ГК РФ. Правила, связанные с наследованием по закону, содержатся и в других 
главах и статьях кодекса. какие же правила следует применять при наследовании по закону и при наследовании «в порядке наследования по закону»? Сам закон на этот счет никаких специальных указаний не содержит. Следовательно, к наследованию «в порядке наследования по закону» применяются правила наследования по закону, в том числе и правила о переходе к наследнику по закону обязанности исполнить завещательный отказ (ст. 1140 ГК РФ). Однако если последовательно придерживаться противоположной точки зрения, то следует признать, что у нас есть третье основание наследования - «в порядке наследования по закону». Тогда можно предположить, что кроме наследования по закону и завещанию имеются и другие основания наследования. В этом случае появятся самостоятельные группы наследников - наследники по праву представления, по праву наследственной трансмиссии, необходимые наследники, подназначенные наследники, наследники, призванные к наследству в результате направленного отказа от наследства другого наследника и т. П. Следуя этой логике, необходимо будет признать, что в отношении всех этих наследников действуют иные правила, чем в отношении наследников по завещанию и по закону. Такое предположение противоречит указанию ст. 1111 ГК РФ, где прямо говорится, что наследование осуществляется по завещанию и по закону.

Следует также обратить внимание на то, что обязанность исполнить завещательный отказ переходит к наследнику, к которому перешла доля наследства наследника, обремененного завещательным отказом. Не только принявший наследство, а любой другой наследник, к которому перешла эта доля, обязан исполнить завещательный отказ. Не случайно законодатель использует понятие «переходит». По закону выморочное имущество переходит к публичному образованию, такому наследнику не требуется принимать наследство.

Зарубежное законодательство при выморочности имущества относит государство или иное публично-правовое образование к наследникам по закону, к которым переходит обязанность исполнить завещательный отказ или завещательное возложение. ${ }^{36}$ Целый ряд кодексов бывших советских республик предусматривают переход обязанности исполнить завещательный отказ в случае наследования имущества как выморочного публично-правовыми образованиями. В случае смерти наследника, на которого была возложена обязанность исполнить легат, или непринятия им наследства «исполнение завещательного

36 В Германии - § 1936, 1942, 1967 BGB - «der Fiskus des Bundensstaats... gesetzlicher Erbe»; в Швейцарии - art. 466 Schweizerisches Zivilgesetzbuch - «Hinterlässt der Erblasser keine Erben, so fällt die Erbschaft an den Kanton, in dem der Erblasser den letzten Wohnsitz gehabt hat, oder an die Gemeinde, die von der Gesetzgebung dieses Kantons als berechtigt bezeichnet wird»; в Австрии - § 760 Österreich Allgemeines Bürgerliches Gesetzbuch (ABGB) - «Wenn kein zur Erbfolge Berechtigter vorhanden ist oder wenn niemand die Erbschaft erwirbt, fällt die Verlassenschaft als ein erbloses Gut dem Staate anheim.Abweichungen von der allgemeinen Erbfolgeordnung»; в Италии - art. 586 Codice Civile - «in mancana di altri succeeccibili, l'eredita e devoluta allo Stato...Lo Stato non risponde dei debiti ereditari e dei legati oltre il valore dei beni acquistati». 
отказа переходит на других наследников, получивших его долю, либо к административно-территориальной единице, если имущество стало выморочным» (п. 5 ст. 1054 ГК Республики Беларусь), «либо к государству или к органу самоуправления граждан, если имущество стало выморочным» (абз. 10 ст. 1132 ГК Республики Узбекистан), «либо к государству, если имущество стало выморочным» (п. 5 ст. 1057 ГК Республики Казахстан), «либо к государству» (п. 5 ст. 1152 Республики Таджикистан), «к государству или органу местного самоуправления, если имущество стало выморочным» (п. 5 ст. 1139 ГК Киргизской Республики).

Последняя проблема, которую хотелось бы обсудить в данной статье, связана с ответственностью наследников по долгам наследодателя. Рассмотрим такую ситуацию: наследник по завещанию принял завещанное ему имущество, которое составляло лишь определенную часть наследственной массы, например, унаследовал завещанную ему квартиру, но не принял загородный земельный участок. Остальное имущество перешло как выморочное к публично-правовому образованию. В каком порядке будут отвечать наследник по завещанию и публично-правовое образование перед кредиторами? В законе сказано, что «наследники, принявшие наследство, отвечают по долгам наследодателя солидарно (статья 323)» (п. 1 ст. 1175 ГК РФ). Однако публично-правовое образование не является наследником, принявщим наследство. Для приобретения им выморочного имущества принятие наследства не требуется (п. 1 ст. 1152 ГК РФ).

В силу прямого указания закона, сформулированного в виде императивной нормы, «наследники, принявшие наследство, отвечают по долгам наследодателя солидарно (статья 323)» (п. 1 ст. 1175 ГК РФ), публично-правовое образование не несет солидарную ответственность по долгам наследодателя вместе с наследниками, принявшими наследство. В отношении публично-правового образования будут действовать общие правила об исполнении обязательства, в котором участвуют несколько должников (ст. 321 ГК РФ). Если бы на публично-правовое образование распространялись общие правила о солидарной ответственности наследников, то кредитор, без всякого сомнения, предъявил бы требование по исполнению обязательства к нему. Возлагать на публичноправовое образование, которому не представлена правовая возможность отказаться от наследства, дополнительное бремя по регрессному требованию к другим наследникам было бы совершенно неразумным.

В завершении нашей статьи хотелось бы отметить, что к наследованию выморочного имущества публично-правовым образованием следует применять все нормы наследования по закону, за исключением случаев, прямо предусмотренных в законе. 


\section{INHERITANCE OF ESCHEATED PROPERTY IN RUSSIA}

The provisions of Art. 1151 of the Civil Code may raise certain questions about the legal nature of the acquisition of escheated property: "Escheated property passes by way of inheritance by operation of law to ownership by Russian Federation..." Why is it that law uses the terms "passes", "by way of inheritance by operation of law" and not "inherit by operation of law" relating to an escheat? Is there a difference between these terms?

The law defines the general category - "Persons who may be called to inheritance" (Article 1116 Civil Code): the citizens and legal persons, Russian Federation, subjects of the Russian Federation, municipal formations, foreign states and international organizations. The citizens, Russian Federation, subjects of the Russian Federation, municipal formations may be called to inheritance by will and by operation of law.

The use of the words "by way of inheritance" by operation of law or by will is equally to the term "inheritance" by operation of law or by will. We could not find any other meaning by grammatical, systematic and dogmatic interpretation.

Key words:

An inheritance by operation of law, the escheated property, the inheritance of the state. 